\title{
Polymorphisms in the Nonmuscle Myosin Heavy Chain 9 Gene (MYH9) Are Associated with Albuminuria in Hypertensive African Americans: The HyperGEN Study
}

\author{
Barry I. Freedman ${ }^{a}$ Jeffrey B. Kopp ${ }^{b}$ Cheryl A. Winkler ${ }^{c}$ George W. Nelson ${ }^{c}$ \\ D.C. Rao ${ }^{d}$ John H. Eckfeldt ${ }^{e}$ Mark F. Leppert ${ }^{f}$ Pamela J. Hicks ${ }^{a}$ Jasmin Divers ${ }^{a}$ \\ Carl D. Langefeld ${ }^{\mathrm{a}}$ Steven C. Hunt ${ }^{f}$

 \\ Diabetes and Digestive and Kidney Diseases, Bethesda, Md., 'Laboratory of Genomic Diversity, SAIC-Frederick, \\ National Cancer Institute, Frederick, Md., 'Washington University School of Medicine, St. Louis, Mo., \\ e University of Minnesota, Minneapolis, Minn., f University of Utah School of Medicine, Salt Lake City, Utah, USA
}

\section{Key Words}

African Americans - Albuminuria - Chronic kidney disease • Essential hypertension $\cdot$ HyperGEN study $\cdot$ MYH9 gene

\begin{abstract}
Background: MYH9 is a podocyte-expressed gene encoding nonmuscle myosin IIA that is associated with idiopathic and human immunodeficiency virus-associated focal segmental glomerulosclerosis (FSGS) and hypertensive end-stage renal disease in African Americans. Methods: Four single nucleotide polymorphisms comprising the major MYH9E1 risk haplotype were tested for association with estimated glomerular filtration rate (eGFR) and urine albumin:creatinine ratio (ACR) in 2,903 HyperGEN participants (1,458 African Americans (AA) in 895 families and 1,445 European Americans (EA) in 859 families) to determine the role of $\mathrm{MYH9}$ in subclinical nephropathy. Association analyses employed general linear models in unrelated probands and generalized estimating equations in families. Adjustment was performed for age, sex, diabetes, BMI, medications, and mean arterial pressure separately in each race. Results: Mean (SD) eGFR and ACR
\end{abstract}

were $74.3(16.0) \mathrm{ml} / \mathrm{min} / 1.73 \mathrm{~m}^{2}$ and $20.3(119.9) \mathrm{mg} / \mathrm{g}$ in EA, and $88.6(20.9) \mathrm{ml} / \mathrm{min} / 1.73 \mathrm{~m}^{2}$ and 76.8 (394.5) $\mathrm{mg} / \mathrm{g}$ in AA (both $p<0.0001$ across ethnicities). Urine ACR was associated with rs3752462 $(p=0.01)$ and $r s 4821481(p=0.05)$ in unrelated AA and with rs4821481 ( $p=0.03), r s 2032487(p=$ $0.04)$ and the E1 3224 haplotype $(p=0.013)$ in AA families. Single nucleotide polymorphisms and the haplotype were not associated with ACR in EA or with eGFR in either ethnic group. Conclusions: MYH9 variants are associated with albuminuria in hypertensive AA. The strength of the association was weaker than that in FSGS and hypertensive end-stage renal disease. MYH9 risk variants appear to be associated with primary FSGS with secondary hypertension, although nephrosclerosis may develop in response to hypertension in subjects homozygous for the MYH9 E1 risk haplotype.

Copyright $\odot 2009$ S. Karger AG, Basel

Names of primary centers and investigators of HyperGEN are given in the appendix.

\section{KARGER}

(ㄷ) 2009 S. Karger AG, Basel

Fax +41613061234 E-Mail karger@karger.ch www.karger.com www.karger.com/ajn
Barry I. Freedman, MD

Section on Nephrology, Wake Forest University School of Medicine

Medical Center Boulevard

Winston-Salem, NC 27157-1053 (USA)

Tel. +1 336716 6192, Fax +1 336716 4318, E-Mail bfreedma@wfubmc.edu 


\section{Introduction}

High blood pressure is strongly associated with the progression of chronic kidney disease (CKD) to end-stage renal failure. However, the role of systemic hypertension in the initiation of arteriolar or hypertensive nephrosclerosis remains controversial [1]. African Americans (AA) are diagnosed with hypertension-associated endstage renal disease (H-ESRD) far more often than European Americans (EA) [2]. Many AA labeled with H-ESRD present to nephrologists late in their course, at a time when it is difficult to determine whether a primary kidney disease initiated the renal failure [3]. Unfortunately, few of these individuals receive kidney biopsies. Many nephrologists code the diagnosis 'hypertensive-ESRD' in nondiabetic AA subjects with unknown cause for CKD, since long-standing secondary hypertension is nearly universally present [4]. Although cross-sectional studies reveal graded relationships between severity of hypertension and CKD, it is not possible to tell which syndrome was causative [5].

Lack of access to adequate healthcare and lower socioeconomic status are associated with risk for nephropathy in sporadic cases of ESRD [6]. In contrast, analysis of geocoded data in incident dialysis patients demonstrated that median family income and level of education were not associated with familially clustered ESRD, suggesting a role for non-socioeconomic status factors, possibly inherited [7]. More than $30 \%$ of AA and $12-15 \%$ of EA with common, complex forms of ESRD have first and/or second degree relatives with ESRD and many more have relatives with silent or unrecognized nephropathy [8].

The recent identification of $M Y H 9$ gene associations in idiopathic and human immunodeficiency virus (HIV)associated focal and segmental glomerulosclerosis (FSGS) and H-ESRD in AA has been a major breakthrough in our understanding of these etiologies of nephropathy $[9$, 10]. The $M Y H 9$ gene association had an odds ratio (OR) of 4-5 in AA with FSGS and HIV-associated nephropathy (HIVAN), and ORs of 1.5-3.4 in H-ESRD [25]. In addition, replacing the $\mathrm{MYH} 9$ risk haplotype with a protective haplotype would reduce nondiabetic ESRD by $70 \%$ in AA. The MYH9 association may account for the failure of antihypertensive therapy, including the use of ACE inhibitors, to substantially slow progression of 'hypertension-associated kidney disease' in AA [11-13] and the clustering of different etiologies of ESRD in single AA families (including FSGS, HIVAN and H-ESRD) [14]. Since the risk haplotype is observed in $60 \%$ of AA and $4 \%$ of EA, polymorphisms in this gene could account for a portion of the ethnic disparity in nondiabetic forms of H-ESRD, HIVAN and FSGS [10].

To date, the MYH9 gene has not been tested for association with markers of nephropathy in hypertensive subjects. We evaluated 4 single nucleotide polymorphisms (SNPs) comprising the major MYH9 risk haplotype (the E1 haplotype) for association with subclinical nephropathy in HyperGEN study participants.

\section{Materials and Methods}

\section{Study Population}

HyperGEN study methods and participants have previously been reported [15]. In brief, HyperGEN is a multicenter crosssectional study charged with identifying and characterizing genes that contribute to hypertension and related phenotypes as part of the National Heart Lung and Blood Institute-sponsored Family Blood Pressure Program (FBPP). HyperGEN consists of five field centers: Framingham (Mass.), Minneapolis (Minn.), Salt Lake City (Utah), Forsyth County (N.C.) and Birmingham (Ala.). Study variables assessed included blood pressures, serum and urine chemistries, anthropometrics, echocardiographic measurements, and basic demographic information including questions about family and personal history of hypertension, medication, diet, physical activity, and lifestyle. DNA extraction was performed.

We analyzed data in all EA and AA HyperGEN participants recruited from hypertensive sibships (including mild and severe hypertension) selected from families with two or more hypertensive siblings diagnosed before 60 years of age, as well as their adult offspring (offspring were not necessarily hypertensive or taking antihypertensive medications). Mild hypertension was defined as a systolic blood pressure (SBP) between 140 and $160 \mathrm{~mm} \mathrm{Hg}$ or diastolic blood pressure (DBP) between 90 and $100 \mathrm{~mm} \mathrm{Hg}$, or taking one antihypertensive medication. Severe hypertension was defined as having an SBP greater than 160 or DBP greater than $100 \mathrm{~mm} \mathrm{Hg}$, or using two or more antihypertensive medications. Renal replacement therapy was an exclusion criterion.

\section{Phenotypes}

The urine albumin:creatinine ratio (ACR) was measured from an overnight urine collection. The distribution of urine ACR was highly skewed, so a logarithm-transformed variable was used for the association analyses. Estimated glomerular filtration rate (eGFR) was computed using the abbreviated MDRD equation, and creatinine clearance calculated from timed urine collections [16].

\section{Statistical Analyses}

Adjustment was performed for age, sex, diabetes, BMI, blood pressure medications, and mean arterial blood pressure, separately in each ethnic group. General linear models were used to test for association when analyzing one subject from each family and generalized estimating equations were used for analyses of all subjects to account for familial relationships. Haplotypes were estimated from PHASE separately for AA and EA [17]. Spacing of the four SNPs was taken from the NCBI website using the base pair starting position of each SNP. Because the study by Kopp et al. [10] identified the at-risk haplotype (3224 or GCCT for 
Table 1. Demographic characteristics of the HyperGEN study population

\begin{tabular}{|c|c|c|c|c|c|c|c|c|c|}
\hline \multirow[t]{2}{*}{ Variable } & \multicolumn{4}{|l|}{ AA } & \multicolumn{4}{|l|}{ EA } & \multirow{2}{*}{$\begin{array}{l}\text { p value } \\
\text { (AA vs. EA) }\end{array}$} \\
\hline & $\mathrm{n}$ & mean & median & SD & $\mathrm{n}$ & mean & median & SD & \\
\hline Age, years & 1,485 & 50.8 & 50.0 & 11.1 & 1,536 & 61.1 & 62.0 & 8.7 & $<0.0001$ \\
\hline $\mathrm{SBP}, \mathrm{mm} \mathrm{Hg}$ & 1,467 & 132.0 & 130.0 & 22.4 & 1,463 & 125.4 & 123.0 & 20.6 & $<0.0001$ \\
\hline $\mathrm{DBP}, \mathrm{mm} \mathrm{Hg}$ & 1,467 & 75.2 & 74.5 & 11.8 & 1,463 & 68.4 & 67.5 & 10.9 & $<0.0001$ \\
\hline Mean arterial pressure, $\mathrm{mm} \mathrm{Hg}$ & 1,467 & 94.1 & 92.5 & 14.1 & 1,463 & 87.4 & 86.5 & 12.7 & $<0.0002$ \\
\hline Serum creatinine, mg/dl & 1,485 & 1.0 & 1.0 & 0.4 & 1,536 & 1.0 & 0.9 & 0.3 & 0.1 \\
\hline Body mass index & 1,483 & 32.4 & 31.2 & 7.6 & 1,534 & 29.8 & 29.0 & 6.0 & $<0.0001$ \\
\hline eGFR, $\mathrm{ml} / \mathrm{min}$ & 1,485 & 88.6 & 87.9 & 20.9 & 1,536 & 74.3 & 73.3 & 16.0 & $<0.0002$ \\
\hline Urine ACR, mg/g & 1,458 & 76.8 & 6.0 & 394.5 & 1,445 & 20.3 & 4.6 & 119.9 & $<0.0001$ \\
\hline Log urine ACR & 1,458 & 2.3 & 1.8 & 1.5 & 1,445 & 1.7 & 1.5 & 1.1 & $<0.0001$ \\
\hline $\mathrm{Cr} \mathrm{Cl}, \mathrm{ml} / \mathrm{min} / 1.73 \mathrm{~m}^{2}$ & 1,226 & 93.4 & 95.1 & 30.0 & 1,408 & 88.0 & 83.4 & 23.7 & $<0.0002$ \\
\hline
\end{tabular}

$\mathrm{Cr} \mathrm{Cl}=$ Creatinine clearance; $\mathrm{SD}=$ standard deviation.

$\mathrm{p}$ values computed from the Wilcoxon two-sample test.

rs4821480, rs2032487, rs4821481, and rs3752462, respectively), this haplotype was tested against all other haplotypes combined. We put special emphasis on the recessive model, previously shown to be the most likely mode of inheritance model for this haplotype. In the original analysis of 17 MYH9 SNPs and their haplotypes, the E1 haplotype was observed to have the strongest association [10]. This was confirmed by a sliding window analysis. More than 100 SNPs in this region of MYH9 have now been genotyped, including virtually all haplotype tagging SNPs in the associated region. There is high linkage disequilibrium between associated SNPs and a causal SNP has not yet been identified, possibly due to the high degree of linkage disequilibrium. Although a few of these new SNPs demonstrated increased significance with somewhat lower $\mathrm{p}$ values compared to the 4 SNPs in the E1 haplotype, these new SNPs fell within the E1 haplotype block and their ORs and 95\% CIs were nearly coincident. Statistically, it would be extremely difficult to separate these effects. The main association effect appears to come from the E1 haplotype in both EA and AA, as the OR for the E1 haplotype association is 7.7 in EA with idiopathic FSGS and 4.7 in AA [10]. This demonstrates that the E1 haplotype is powerfully associated with kidney disease in both ethnic groups. Genotyping additional SNPs in this region would not be likely to provide significant additional information.

\section{Genotyping}

The 4 SNPs evaluated were rs4821480, rs2032487, rs4821481 and rs3752462. SNP genotyping was performed on a TaqMan machine (Applied Biosystems, Foster City, Calif., USA) using standard methods.

\section{Results}

The study population consisted of 2,903 HyperGEN participants, 1,458 AA from 895 families and 1,445 EA from 859 families. Clinical and demographic character- istics of the study population are presented in table 1. Although mean (SD) arterial blood pressures were fairly well controlled, they were lower in the EA $(87.4 \pm 12.7$ $\mathrm{mm} \mathrm{Hg})$ than the AA participants $(94.1 \pm 14.1 \mathrm{~mm} \mathrm{Hg}$; $\mathrm{p}<0.0001)$. Mean (SD) eGFR and ACR, respectively, were $74.3(16.0) \mathrm{ml} / \mathrm{min} / 1.73 \mathrm{~m}^{2}$ and 20.3 (119.9) $\mathrm{mg} / \mathrm{g}$ in EA subjects, and $88.6(20.9) \mathrm{ml} / \mathrm{min} / 1.73 \mathrm{~m}^{2}$ and 76.8 (394.5) $\mathrm{mg} / \mathrm{g}$ in AA subjects $(\mathrm{p}<0.0001$ for both ACR and GFR across race groups). Diabetes was present in $260 \mathrm{EA}$ and 354 AA.

The results of the single SNP analyses in unrelated cases and in members of HyperGEN families are presented in tables 2 and 3, respectively. In the unrelated AA cases, urine ACR was significantly associated with rs3752462 $(\mathrm{p}=0.01)$ and $\mathrm{rs} 4821481(\mathrm{p}=0.05)$, and a nonsignificant trend toward association was observed for rs2032487 $(\mathrm{p}=0.08)$. In the AA families, urine ACR was also significantly associated with rs4821481 $(\mathrm{p}=0.03)$ and $\mathrm{rs} 2032487$ $(\mathrm{p}=0.04)$, with a nonsignificant trend for $\mathrm{rs} 3752462(\mathrm{p}=$ $0.07)$. No SNPs were associated with urine ACR in EA and no significant associations with eGFR were observed in participants of either race (EA data not shown).

Of note, 3 of the 1,445 EAs in HyperGEN were homozygous for the rs2032487 susceptibility variant. These subjects had a very low mean eGFR $=30.3 \mathrm{ml} / \mathrm{min} /$ $1.73 \mathrm{~m}^{2}$ (vs. 87.4 and $89.1 \mathrm{ml} / \mathrm{min} / 1.73 \mathrm{~m}^{2}$ for heterozygotes and those homozygous for the resistant variant, respectively).

The GCCT (3224) haplotype of rs4821480, rs2032487, rs4821481, and rs 3752462 was found in 3.9\% of EA (three haplotypes were present in $>1 \%$ of the population) and 
Table 2. Single SNP associations in unrelated AA, using generalized linear models

\begin{tabular}{|c|c|c|c|c|c|c|}
\hline \multirow[t]{2}{*}{ SNP } & \multirow[t]{2}{*}{$\begin{array}{l}\mathrm{p} \text { value } \\
\text { for eGFR }\end{array}$} & \multirow{2}{*}{$\begin{array}{l}\mathrm{p} \text { value } \\
\text { for urine } \\
\mathrm{ACR}\end{array}$} & \multicolumn{2}{|c|}{ Mean log urine ACR } & \multicolumn{2}{|c|}{$\begin{array}{l}\text { Mean urine ACR } \\
\text { (original scale } \mathrm{mg} / \mathrm{g} \text { ) }\end{array}$} \\
\hline & & & $\begin{array}{l}\text { risk } \\
\text { homozygotes }\end{array}$ & $\begin{array}{l}\text { protective } \\
\text { homozygotes }\end{array}$ & $\begin{array}{l}\text { risk } \\
\text { homozygotes }\end{array}$ & $\begin{array}{l}\text { protective } \\
\text { homozygotes }\end{array}$ \\
\hline rs4821480 & 0.6 & 0.6 & 2.30 & 2.17 & 12.2 & 10.2 \\
\hline rs2032487 & 0.8 & 0.08 & 2.36 & 2.18 & 12.9 & 10.0 \\
\hline rs4821481 & 0.8 & 0.05 & 2.38 & 2.17 & 13.0 & 9.8 \\
\hline rs3752462 & 0.7 & 0.01 & 2.36 & 2.22 & 12.6 & 10.3 \\
\hline
\end{tabular}

Table 3. Single SNP associations in all AA, using GENMOD

\begin{tabular}{|c|c|c|c|c|c|c|}
\hline \multirow[t]{2}{*}{ SNP } & \multirow{2}{*}{$\begin{array}{l}\mathrm{p} \text { value } \\
\text { for eGFR }\end{array}$} & \multirow{2}{*}{$\begin{array}{l}p \text { value } \\
\text { for log } \log _{e} \\
\text { urine ACR }\end{array}$} & \multicolumn{2}{|c|}{$\log _{e}$ urine $\mathrm{ACR}(\mathrm{SE})$} & \multicolumn{2}{|c|}{ Mean urine ACR } \\
\hline & & & $\begin{array}{l}\text { risk } \\
\text { homozygotes }\end{array}$ & $\begin{array}{l}\text { protective } \\
\text { homozygotes }\end{array}$ & $\begin{array}{l}\text { risk } \\
\text { homozygotes }\end{array}$ & $\begin{array}{l}\text { protective } \\
\text { homozygotes }\end{array}$ \\
\hline rs4821480 & 0.5 & 0.15 & $2.32(0.06)$ & $2.12(0.11)$ & 12.37 & 9.19 \\
\hline rs2032487 & 0.9 & 0.04 & $2.36(0.06)$ & $2.15(0.11)$ & 12.8 & 9.28 \\
\hline rs4821481 & 0.9 & 0.03 & $2.37(0.06)$ & $2.13(0.11)$ & 12.8 & 9.07 \\
\hline rs3752462 & 0.4 & 0.07 & $2.33(0.06)$ & $2.16(0.14)$ & 12.25 & 8.84 \\
\hline
\end{tabular}

$62.9 \%$ of AA (five haplotypes were present in $>1 \%$ of the population). Among HyperGEN participants, $38.88 \%$ of $\mathrm{AA}$ and $0.13 \%$ of EA were homozygous for the $3224 \mathrm{E} 1$ risk haplotype. Forming the E1 risk haplotype improved the significance of the urine ACR association results. Table 4 reveals that urine ACR was associated with having two copies of the E1 risk haplotype in AAs [p = 0.013; log urine ACR (standard error, SE) = $2.37(0.06)$ for risk haplotype homozygotes vs. 2.18 (0.05) for nonrisk), corresponding to urine ACR values of $12.8 \mathrm{mg} / \mathrm{g}$ and 10.7 $\mathrm{mg} / \mathrm{g}$, respectively. Table 5 reveals the lack of association of MYH9 E1 SNPs with type 2 diabetes mellitus by ethnicity ( $\chi^{2}$ test, 2 d.f.).

\section{Discussion}

We sought to determine whether SNPs in the E1 risk haplotype of the MYH9 gene were associated with subclinical nephropathy in a large sample of EA and AA hypertensive sibling pairs and their offspring in the HyperGEN study. Siblings were concordant for high blood pressure and had concomitant measures of albuminuria and kidney function. After adjusting for diabetes and the se- verity of hypertension, albuminuria was significantly associated with several SNPs comprising the MYH9 E1 risk haplotype in AA participants, and the haplotype had a $\mathrm{p}$ value of 0.013 for association with urine ACR. This suggests that some AA in HyperGEN may have had a primary kidney disease, possibly FSGS with secondarily elevated blood pressure, or that high blood pressure directly caused albuminuria in a subset of genetically predisposed individuals. It is clear that not all HyperGEN participants had essential hypertension, as subjects with mild to moderate kidney disease not requiring renal replacement therapy were eligible for recruitment [15].

Identification of the MYH9 association with FSGS, HIVAN, and H-ESRD, as well as other podocyte genes encoding podocin, nephrin, $\alpha$-actinin 4 , CD2-associated protein and TRPC6 as causes of complex kidney disease, has altered our understanding of the importance of the podocyte and its cytoskeleton in forming a nearly proteinfree urine and maintaining normal renal function and histology [9, 10, 18-21]. The strong MYH9 association with what has been clinically labeled 'hypertension-associated ESRD', coupled with the failure of strict blood pressure control and use of ACE inhibitors to forestall ESRD in hypertensive AA with CKD, suggests that segmental 
Table 4. Comparison between mean urine ACR, eGFR and creatinine clearance, by haplotype and ethnicity

\begin{tabular}{|c|c|c|c|c|c|c|c|c|}
\hline \multirow[t]{2}{*}{ Ethnicity } & \multirow[t]{2}{*}{ Haplotype } & \multicolumn{3}{|c|}{ Mean urine ACR } & \multicolumn{2}{|l|}{ eGFR } & \multicolumn{2}{|c|}{ Creatinine clearance } \\
\hline & & $\log _{\mathrm{e}}$ scale & $\mathrm{mg} / \mathrm{g}$ & p value ${ }^{1}$ & mean & $\mathrm{p}$ value & mean & $\mathrm{p}$ value \\
\hline \multirow{2}{*}{ AA } & 3224 & $2.37(0.06)$ & 12.8 & \multirow[t]{2}{*}{0.013} & $88.8(0.69)$ & \multirow[t]{2}{*}{0.45} & $94.9(0.96)$ & \multirow[t]{2}{*}{0.41} \\
\hline & Not 3224 & $2.18(0.05)$ & 10.7 & & $88.0(0.87)$ & & $93.4(1.16)$ & \\
\hline \multirow[t]{2}{*}{ EA } & 3224 & $1.6(0.09)$ & $4.8^{2}$ & \multirow[t]{2}{*}{0.49} & $29.0(1.19)$ & \multirow[t]{2}{*}{0.31} & $29.8(1.65)$ & \multirow[t]{2}{*}{0.31} \\
\hline & Not 3224 & $1.7(0.03)$ & 3.8 & & $74.6(0.45)$ & & $88.5(0.58)$ & \\
\hline
\end{tabular}

eGFR in $\mathrm{ml} / \mathrm{min} / 1.73 \mathrm{~m}^{2}$, creatinine clearance in $\mathrm{ml} / \mathrm{min}$. Figures in parentheses indicate SEs.

${ }^{1}$ Computed from the log-normal model, not the original scale. ${ }^{2}$ This haplotype was observed in only 2 EA individuals.

Table 5. MYH9 SNP associations with diabetes $\left(\chi^{2} ; 2\right.$ d.f.) by ethnicity

\begin{tabular}{|c|c|c|c|c|c|c|c|c|c|}
\hline \multirow[t]{3}{*}{ SNP } & \multirow[t]{3}{*}{ Genotypes } & \multicolumn{4}{|l|}{$\mathrm{AA}$} & \multicolumn{4}{|l|}{ EA } \\
\hline & & \multicolumn{2}{|c|}{ T2DM } & \multirow[t]{2}{*}{$\chi^{2}$} & \multirow[t]{2}{*}{$\mathrm{p}$ value } & \multicolumn{2}{|c|}{ T2DM } & \multirow[t]{2}{*}{$\chi^{2}$} & \multirow[t]{2}{*}{$\mathrm{p}$ value } \\
\hline & & no & yes & & & no & yes & & \\
\hline \multirow[t]{3}{*}{ rs2032487 } & CC & 511 & 164 & \multirow[t]{3}{*}{0.69} & \multirow[t]{3}{*}{0.7} & 2 & 0 & \multirow[t]{3}{*}{0.41} & \multirow[t]{3}{*}{0.8} \\
\hline & $\mathrm{CT}$ & 467 & 148 & & & 96 & 20 & & \\
\hline & TT & 133 & 36 & & & 1,149 & 238 & & \\
\hline \multirow[t]{3}{*}{ rs3752462 } & GG & 75 & 18 & \multirow[t]{3}{*}{1.20} & \multirow[t]{3}{*}{0.5} & 579 & 118 & \multirow[t]{3}{*}{1.75} & \multirow[t]{3}{*}{0.4} \\
\hline & GT & 419 & 131 & & & 550 & 119 & & \\
\hline & TT & 630 & 204 & & & 136 & 21 & & \\
\hline \multirow[t]{3}{*}{ rs4821481 } & $\mathrm{CC}$ & 490 & 160 & \multirow[t]{3}{*}{0.67} & \multirow[t]{3}{*}{0.7} & 2 & 0 & \multirow[t]{3}{*}{0.44} & \multirow[t]{3}{*}{0.8} \\
\hline & CT & 505 & 157 & & & 94 & 20 & & \\
\hline & TT & 134 & 37 & & & 1,173 & 238 & & \\
\hline \multirow[t]{3}{*}{ rs4821480 } & $\mathrm{CC}$ & 584 & 178 & \multirow[t]{3}{*}{0.76} & \multirow[t]{3}{*}{0.7} & 2 & 0 & \multirow[t]{3}{*}{0.44} & \multirow[t]{3}{*}{0.8} \\
\hline & $\mathrm{CT}$ & 393 & 132 & & & 93 & 20 & & \\
\hline & TT & 128 & 37 & & & 1,155 & 237 & & \\
\hline
\end{tabular}

and global forms of glomerulosclerosis may be primary renal diseases that lead to progressive nephropathy [1113]. The MYH9 association with albuminuria in AA HyperGEN participants, after adjustment for severity of hypertension, suggests that elevated blood pressures in participants could have been a secondary phenomenon related to an intrinsic kidney disease. The renal microvascular changes previously felt to be the sine qua non of hypertensive kidney disease, arteriolar and arterial nephrosclerosis do not correlate with systemic blood pressures in African American Study of Hypertension and Kidney Disease participants, and the vast majority of nondiabetic AA with hypertension and CKD had renal biopsies revealing global and/or segmental forms of glomeruloscle- rosis with interstitial fibrosis [22]. Patients with classic clinical scenarios for hypertensive nephrosclerosis have also been shown to have FSGS on kidney biopsy [23, 24].

These results suggest that AA subjects in the HyperGEN study who are genetically susceptible to the development of a primary kidney disease based upon the MYH9 genotype have significantly higher levels of urinary albumin excretion. Although the observed differences in urinary albumin excretion were statistically significant based on genotype, the differences were not clinically significant. Therefore, individuals with MYH9 risk genotypes and slightly high urine ACR will need to be followed longitudinally in order to determine whether renal insufficiency or higher levels of proteinuria ultimately develop. 
It is possible that excessive albuminuria, independent of the presence of systemic hypertension, is due to idiopathic FSGS or the early stages of what has been labeled $\mathrm{H}$ ESRD, based on the strong MYH9 association with these renal diseases. However, it remains possible that high blood pressure causes subsequent kidney disease or nephrosclerosis mainly in genetically susceptible individuals.

The strength of the MYH9 association with albuminuria was markedly reduced in this study sample, as it was not enriched for severe forms of nephropathy. For example, the E1 risk haplotype association with nondiabetic ESRD in AA residing in the southeastern U.S. was on the order of $\mathrm{p}=10^{-15}$, with an OR of $2.38[10,25]$. Similarly, nondiabetic ESRD subjects in the Family Investigation of Nephropathy and Diabetes revealed p values for disease association of $10^{-15}$ for several individual MYH9 SNPs, with similar ORs. Since severe kidney disease was infrequent in HyperGEN participants, we could not detect associations with either eGFR or creatinine clearance. In total, the MYH9 association with FSGS, HIVAN and HESRD has been replicated in 5 distinct cohorts containing individuals with advanced nephropathy $[9,10,25]$. MYH9 E1 risk haplotype frequencies in EA and AA participants from HyperGEN were similar to those in the general populations, despite enrichment for the presence of high blood pressure.

In conclusion, the MYH9 gene is the proximate cause of many cases of FSGS, HIVAN and H-ESRD in the AA population, an effect likely due to alterations in the podocyte cytoskeleton [26]. This gene has shown pronounced evidence of association in common, complex forms of nephropathy $[9,10,25]$. The current cross-sectional analysis assessed for MYH9 SNP and E1 haplotype associations with albuminuria and kidney function in a large biracial cohort of essential hypertensives. This is the first analysis to search for associations with quantitative measures of subclinical kidney disease in a sample not enriched for nephropathy. In contrast to prior reports, the MYH9 E1 haplotype was not as strongly associated with albuminuria as it was with severe kidney diseases and ESRD. These results suggest that most hypertensive AA are not at extreme risk for developing subsequent nephropathy, a result that has clearly been demonstrated in the Multiple Risk Factor Intervention Trial and Hypertension Detection and FollowUp Program cohorts [27, 28]. Longitudinal studies in AA subjects with MYH9 risk alleles will be required to determine whether high blood pressure is the result of a primary kidney disease such as FSGS or whether nephrosclerosis with albuminuria develops in hypertensive subjects homozygous for MYH9 risk SNPs and haplotypes.

\section{Acknowledgments}

The HyperGEN network is funded by National Heart, Lung, and Blood Institute R01 HL55673 and cooperative agreements (U10) with National Heart, Lung, and Blood Institute: HL54471 (Utah FC), HL54472 (Minn. Lab), HL54473 (DCC), HL54495 (Ala. FC), HL54496 (Minn. FC), HL54509 (N.C.), HL54515 (Utah DNA Lab). This work was also supported in part by NIH grant RO1 DK 070942 (B.I.F.). This project has been funded in whole or in part with federal funds from the National Cancer Institute, National Institutes of Health, under contract N01-CO-12400 and HHSN261200800001E. The content of this publication does not necessarily reflect the views or policies of the Department of Health and Human Services, nor does mention of trade names, commercial products, or organizations imply endorsement by the U.S. Government. This research was supported (in part) by the Intramural Research Program of the NIH, National Cancer Institute, Center for Cancer Research.

\section{Appendix}

\section{Primary Centers and Investigators of HyperGEN}

This Hypertension Network is funded by Cooperative Agreements (U10) with National Heart Lung and Blood Institute: HL54471, HL54472, HL54473, HL54495, HL54496, HL54497, HL54509, HL54515.

University of Utah (Network Coordinating Center, Field Center, and Molecular Genetics Lab): Steven C. Hunt, PhD (Network Director and Field Center P.I.); Mark F. Leppert, PhD (Molecular Genetics P.I.); Jean-Marc Lalouel, MD, DSc; Robert B. Weiss, PhD; Roger R. Williams, MD (late); Janet Hood.

University of Alabama at Birmingham (Field Center): Cora E. Lewis, MD, MSPH (P.I.); Albert Oberman, MD, MPH; Donna Arnett, PhD; Phillip Johnson; Christie Oden.

Boston University (Field Center): Richard H. Myers, PhD (P.I.); R. Curtis Ellison, MD; Yuqing Zhang, MD; Jemma B. Wilk, DSc; Luc Djoussé, MD, DSc; Jason M. Laramie; Greta Lee Splansky, MS.

University of Minnesota (Field Center and Biochemistry Lab): James S. Pankow, PhD (Field Center P.I.); Michael B. Miller, PhD; Michael Li, PhD; John H. Eckfeldt, MD, PhD (Biochemistry Lab P.I.); Anthony A. Killeen, MD, PhD; Catherine Leiendecker-Foster, MS; Jean Bucksa; Greg Rynders.

University of North Carolina (Field Center): Kari E. North, PhD (P.I.); Barry I. Freedman, MD; Gerardo Heiss, MD.

Washington University (Data Coordinating Center): D.C. Rao, PhD (P.I.); Charles Gu, PhD; Treva Rice, PhD; Aldi T. Kraja, DSc, PhD; Gang Shi, PhD; Yun Ju Sung, PhD; Karen L. Schwander, MS; Stephen Mandel; Shamika Ketkar; Matthew Brown; Michael A. Province, PhD; Ingrid Borecki, PhD; Derek Morgan.

Weil Cornell Medical College (Echo Reading Center): R.B. Devereux, MD; Giovanni de Simone, MD; Jonathan N. Bella, MD.

National Heart, Lung, and Blood Institute: Cashell Jaquish, $\mathrm{PhD}$; Dina Paltoo, PhD. 


\section{References}

-1 Freedman BI, Iskandar SS, Appel RG: The link between hypertension and nephrosclerosis. Am J Kidney Dis 1995;25:207-221.

$\checkmark 2$ United States Renal Data Systems Annual (USRDS) 2006 Report. Am J Kidney Dis 2007;49:S1.

3 Schlessinger SD, Tankersley MR, Curtis JJ: Clinical documentation of end-stage renal disease due to hypertension. Am J Kidney Dis 1994;23:655-660.

4 Zarif L, Covic A, Iyengar S, Sehgal AR, Sedor JR, Schelling JR: Inaccuracy of clinical phenotyping parameters for hypertensive nephrosclerosis. Nephrol Dial Transplant 2000; 15:1801-1807.

5 Klag MJ, Whelton PK, Randall BL, Neaton JD, Brancati FL, Ford CE, Shulman NB, Stamler J: Blood pressure and end-stage renal disease in men. N Engl J Med 1996;334: 13-18.

6 Perneger TV, Whelton PK, Klag MJ: Race and end-stage renal disease. Socioeconomic status and access to health care as mediating factors. Arch Intern Med 1995; 155:12011208.

7 Song EY, McClellan WM, McClellan A, Gadi R, Krisher J, Clay M, Freedman BI: The effect of neighborhood characteristics on family history (FH) of ESRD (abstract). J Am Soc Nephrol 2008, in press.

8 Freedman BI, Volkova NV, Satko SG, Krisher J, Jurkovitz C, Soucie JM, McClellan WM: Population-based screening for family history of end-stage renal disease among incident dialysis patients. Am J Nephrol 2005;25: 529-535.

9 Kao WH, Klag MJ, Meoni LA, Reich D, Berthier-Schaad Y, Li M, Coresh J, Patterson N, Tandon A, Powe NR, Fink NE, Sadler JH, Weir MR, Abboud HE, Adler SG, Divers J, Iyengar SK, Freedman BI, Kimmel PL, Knowler WC, Kohn OF, Kramp K, Leehey DJ, Nicholas SB, Pahl MV, Schelling JR, Sedor JR, Thornley-Brown D, Winkler CA, Smith MW, Parekh RS: MYH9 is associated with nondiabetic end-stage renal disease in African Americans. Nat Genet 2008;40: 1185-1192.

-10 Kopp JB, Smith MW, Nelwson GW, Johnson RC, Freedman BI, Bowden DW, Oleksyk T, McKenzie LM, Kajiyama H, Ahuja TS, Berns JS, Briggs W, Cho ME, Dart RA, Kimmel PL, Korbet SM, Michel DM; Mokrzycki MH, Schelling JR, Simon E, Trachtman H, Vlahov D, Winkler CA: MYH9 is a major-effect risk gene for focal segmental glomeulosclerosis. Nat Genet 2008;40:1175-1184.
11 Agodoa LY, Appel L, Bakris GL, Beck G, Bourgoignie J, Briggs JP, Charleston J, Cheek D, Cleveland W, Douglas JG, Douglas M, Dowie D, Faulkner M, Gabriel A, Gassman J, Greene T, Hall Y, Hebert L, Hiremath L, Jamerson K, Johnson CJ, Kopple J, Kusek J, Lash J, Lea J, Lewis JB, Lipkowitz M, Massry S, Middleton J, Miller ER III, Norris K, O’Connor D, Ojo A, Phillips RA, Pogue V, Rahman M, Randall OS, Rostand S, Schulman G, Smith W, Thornley-Brown D, Tisher CC, Toto RD, Wright JT Jr, Xu S: Effect of ramipril vs amlodipine on renal outcomes in hypertensive nephrosclerosis: a randomized controlled trial. JAMA 2001;285:2719-2728.

12 Appel LJ, Wright JT Jr, Greene T, Kusek JW, Lewis JB, Wang X, Lipkowitz MS, Norris KC, Bakris GL, Rahman M, Contreras G, Rostand SG, Kopple JD, Gabbai FB, Schulman GI, Gassman JJ, Charleston J, Agodoa LY: Long-term effects of renin-angiotensin system-blocking therapy and a low blood pressure goal on progression of hypertensive chronic kidney disease in African Americans. Arch Intern Med 2008;168:832-839.

13 Rostand SG, Brown G, Kirk KA, Rutsky EA, Dustan HP: Renal insufficiency in treated essential hypertension. N Engl J Med 1989; 320:684-688.

-14 Freedman BI, Spray BJ, Tuttle AB, Buckalew VM: The familial risk of end-stage renal disease in African Americans. Am J Kidney Dis 1993;21:387-393.

15 Williams RR, Rao DC, Ellison RC, Arnett DK, Heiss G, Oberman A, Eckfeldt JH, Leppert MF, Province MA, Mockrin SC, Hunt SC: NHLBI family blood pressure program: methodology and recruitment in the HyperGEN network. Hypertension genetic epidemiology network. Ann Epidemiol 2000;10: 389-400.

16 Levey AS, Bosch JP, Lewis JB, Greene T, Rogers N, Roth D: A more accurate method to estimate glomerular filtration rate from serum creatinine: a new prediction equation. Modification of Diet in Renal Disease Study Group. Ann Intern Med 1999;130:461-470.

-17 Stephens M, Smith NJ, Donnelly P: A new statistical method for haplotype reconstruction from population data. Am J Hum Genet 2001;68:978-989.

18 Faul C, Asanuma K, Yanagida-Asanuma E, Kim K, Mundel P: Actin up: regulation of podocyte structure and function by components of the actin cytoskeleton. Trends Cell Biol 2007; 17:428-437.

$>19$ Kaplan JM, Kim SH, North KN, Rennke H, Correia LA, Tong HQ, Mathis BJ, RodriguezPerez JC, Allen PG, Beggs AH, Pollak MR: Mutations in ACTN4, encoding alpha-actinin-4, cause familial focal segmental glomerulosclerosis. Nat Genet 2000;24:251256.
20 Lenkkeri U, Mannikko M, McCready P, Lamerdin J, Gribouval O, Niaudet PM, Antignac CK, Kashtan CE, Homberg C, Olsen A, Kestila M, Tryggvason K: Structure of the gene for congenital nephrotic syndrome of the Finnish type (NPHS1) and characterization of mutations. Am J Hum Genet 1999;64: 51-61.

-21 Mukerji N, Damodaran TV, Winn MP: TRPC6 and FSGS: the latest TRP channelopathy. Biochim Biophys Acta 2007;1772: 859-868.

22 Fogo A, Breyer JA, Smith MC, Cleveland WH, Agodoa L, Kirk KA, Glassock R: Accuracy of the diagnosis of hypertensive nephrosclerosis in African Americans: a report from the African American Study of Kidney Disease (AASK) Trial. AASK Pilot Study Investigators. Kidney Int 1997;51: 244-252.

23 Freedman BI, Iskander SS, Buckalew VM Jr, Burkart JM, Appel RG: Renal biopsy findings in presumed hypertensive nephrosclerosis. Am J Nephrol 1994;14:90-94.

24 Marcantoni C, Ma LJ, Federspiel C, Fogo AB: Hypertensive nephrosclerosis in African Americans versus Caucasians. Kidney Int 2002;62:172-180.

25 Freedman BI, Hicks PJ, Bostrom MA, Cunningham ME, Liu M, Divers J, Kopp JB, Winkler CA, Nelson GW, Langefeld CD, Bowden DW: Polymorphisms in the nonmuscle myosin heavy chain 9 gene (MYH9) are strongly associated with end-stage renal disease historically attributed to hypertension in African Americans. Kidney International 2009, in press. DOI: $\underline{10.1038 /}$ ki.2008.701.

26 Freedman BI, Sedor JR: Hypertension-associated kidney disease: Perhaps no more. J Am Soc Nephrol 2008;19:2047-2051.

27 Shulman NB, Ford CE, Hall WD, Blaufox MD, Simon D, Langford HG, Schneider KA: Prognostic value of serum creatinine and effect of treatment of hypertension on renal function. Results from the hypertension detection and follow-up program. The Hypertension Detection and Follow-up Program Cooperative Group. Hypertension 1989;13: I80-I93.

28 Walker WG, Neaton JD, Cutler JA, Neuwirth $\mathrm{R}$, Cohen JD: Renal function change in hypertensive members of the Multiple Risk Factor Intervention Trial. Racial and treatment effects. The MRFIT Research Group. JAMA 1992;268:3085-3091. 